\title{
DIE INVLOED VAN DIE GODSDIENS OP DIE VORMING VAN DIE AFRIKAANSE KARAKTER
}

DS. J. N. WOLMARANS

\section{A. Inleidend.}

Jan van Riebeeck, stigter van die Kaapkolonie in die 17de eeu, het uit Protestantse Nederland gekom waar die Calvinistiese Hervormingsrigting deur die meerderheid van mense aangehang is. Dit spreek dus vanself dat hy en sy medestigters dieselfde godsdiens aan die Kaap sou bely en beoefen. Trouens, dit is 'n feit dat heel van die begin af doelbewus daarna gestreef is om die gereformeerde godsdiens aan die Kaap te vestig en die hele volksplanting hierdie leer te laat aanhang. Die voorgeskrewe gebed waarmee Van Riebeeck die sittings van die Politieke Raad moes open, gee hiervan 'n aanduiding. En dit was dan ook min of meer die verloop van kerklike en godsdienstige ontwikkelinge aan die Kaap vanaf die stigting tot meer as 'n honderd jaar daarna. Een godsdiensrigting het oorheers.

Nadat die verversingspos gevestig is en meer mense begin aankom het, terwyl die geleidelike uitbreiding na die binneland stadig in beweging begin kom het, is selfs doelbewuste pogings aangewend om slegs aanhangers van die gereformeerde godsdiens daar toe te laat en die vestiging van ander kerke te ontmoedig. Die enkele Roomse Katolieke wat daar byvoorbeeld was, moes beweeg word om van oortuiging te verander en hierdie godsdiens te aanvaar.

Selfs die Protestantse Lutherse Kerk, wat vanweë heelwat Duitsers wat aan die volksstigting deelgeneem het en steeds as nuwe immigrante aangekom het, 'n heelwat sterker groep was, het meer as 'n eeu gesukkel om toestemming tot die stigting van 'n eie gemeente van die owerheid te verkry. Eers in 1779 is hulle deur die Here 17 toegelaat om tot sodanige stigting oor te gaan en toe is die berig met "leedwese" deur die Kaapse Kerkraad ontvang.

Netsomin as die Roomse Katolieke kon hulle egter ooit 'n be dreiging vir die oorheersende posisie van die gereformeerde godsdiens word, omdat hulle getalle relatief altyd klein was en hulle hoofsaaklik in Kaapstad gekonsentreer was.

Die koms van die Hugenote in 1688 het aan hierdie situasie geesins verander nie, trouens dit eerder verstewig, omdat hulle van dieselfde godsdiensrigting was. Hierdie feit het juis daartoe meegewerk dat die Hugenote maklik met die jong, nuwe, wordende volk kon assimileer. Die godsdiens was in hierdie geval 
beslis die sement wat die verskillende dele aanmekaar gevoeg het, bo-oor die taalverskille heen.

Hierdie feit dat die Calvinisme die oorheersende godsdiens van die begin af was, het uiters belangrike gevolge gehad vir die nuwe volk wat later uit hierdie Nederlandse verversingspos sou groei. Godsdiens, en veral as dit die Calvinisme is, oefen 'n diepgaande invloed op die karaktervorming en persoonlikheidsontwikkeling van sy belyers uit, indiwidueel en gesamentlik. Dit is seker een van die belangrikste faktore wat 'n lewenshouding, 'n lewens- en wêreldbeskouing vorm. Godsdiens maak 'n mens, maak hom die persoon wat hy is, vorm sy rangorde van waardevoorkeur. Daarom kan baie van die tipiese eienskappe van enige volk na sy godsdiens terug herlei word. So kan baie van die karaktereie van die Afrikanervolk na die Calvinisme herlei word

\section{B. Godsdiens aan die vroeë Kaap.}

Saam met Jan van Riebeeck in 1652 is 'n sieketrooster, Willem Barents Wylant gestuur om aanvanklik die godsdiensoefeninge aan die Kaap te lei. Hierdie sieketroosters, waarvan daar later 'n hele aantal aan die Kaap was, was wel onopgeleide persone wat slegs geskrewe preke kon voorlees, in die diens var, die gebede kon voorgaan en die kategetiese onderrig uit 'n voorgeskrewe handboek kon waarneem, maar het aan die vroeë Kaap 'n baie belangrike funksie vervul. Hulle het in 'n wilde, ongetemde wêreld die leiding geneem om die godsdiensbeoefening lewend te hou. Die Kerk in Suid-Afrika is aan hulle baie verskuldig.

Van die begin af het Wylant elke aand na ete in teenwoordigheid van die hele nedersetting 'n gebed gedoen en 'n paar psalmverse laat sing. Die begin van die Kerk in Suid-Afrika was dus baie beskeie. Op Sondae het hy 'n leesdiens gehou en die jong matrose kategetiese onderrig gegee. Versuim om hierdie godsdiensbyeenkomste by te woon is buitengewoon swaar gestraf - ' $n$ bewys dat van meet af aan gepoog is om die volksplanting 'n Christelike karakter te laat aanneem.

Hierdie patroon is min of meer gevolg deur Wylant se opvolgers, Van der Stael, Back en Graa, tot met die koms van 'n opgeleide geordende predikant, ds. Johan van Arckel in 1665. Van to af is die Kerk aan die Kaap behoorlik georganiseer. Steeds meer predikante is deur die Kompanjie gestuur en, soos wat die kolonie se grense uitgebrei het, is nuwe gemeentes afgestig. Al was die vordering miskien stadig en al was die Kaapse Kerk vir baie jare nog afhanklik van en onderhorig aan 
die Klassis van Amsterdam in Nederland, het die georsaniseerde godsdiens dus eintlik saam met die volksplanting gegroei en gou 'n integrale deel van die samelewing geword. En sonder invloed sou dit vanselfsprekend op die wordende Afrikanervolk nie wees nie. Vanweë die uitgestrektheid van die gebied, die lang afstande wat die koloniserende trekboere later van mekaar geskei het, het die Kerk ' $n$ belangrike saambindende faktor en die sentrum van sosiale lewe geword. By die Kerk het almal saamgekom en hierdie verskynsel sou vir baie jare tradisioneel van hierdie volk word.

In hierdie verband moet van een probleem melding gemaak word. Spoedig na die volksplanting en die toetrede tot die boerderybedryf deur die vryburgers, het daar 'n geleidelike koloniseringsproses na die binneland ontwikkel - hoofsaaklik om ekonomiese redes en die soeke na lewensruimte vir die veeboere. Die boere op die voorposte was dus naderhand ver van die sentra van maatskaplike en Kerklike lewe verwyder. Gou was die afstande eenvoudig te groot vir hierdie mense om gereeld aan Kerklike aktiwiteite deel te neem. Die gewoonte het gevolglik ontstaan om slegs by geleentheid van sakramentsbediening en huweliksbevestiging die lang reise af te lê en verder maar self gereelde godsdiensoefeninge in die huis te hou. Hierdie kenmerkende gewoonte van die Afrikanervolk het eers in resente tye begin verander en was vir sy hele wordingsgeskiedenis tiperend.

Maar, op watter wyse ookal, godsdiensbeoefening was van clie begin af leefwyse van die volk wat Jan van Riebeeck help stig het. Die Kerklike organisasie was daar, die lewende Christelike geloof in die hart en die huisgesin was daar. En dit het ' $n$ leidende rol gespeel in die karaktervorming van 'n nuwe volk.

\section{Die Invloed van die Calvinisme.}

Die Calvinisme is 'n praktiese en dinamiese godsdiens wat sy invloed wil laat geld op alle terreine van menslike bestaan. Dit laat hom dus van niks uitsluit of afgrens asof daar sekere gebiede is wat vir die godsdiens taboe is nie. Daarom het volkere wat hierdie leer aangeneem het deur die geskiedenis heen altyd sekere tipiese karaktereienskappe openbaar. Die Calvinisme druk sy stempel af op en deursuur die ganse spektrum van mens-wees. Daarom kan so 'n mens of volk altyd tussen ander uitgeken word.

Dit was nie anders met die nuwe volk wat in die 17de eeu aan die Kaap ontstaan het nie. Die Calvinisme het hierdie volk wesenlik beinvloed, sy karakter, sy lewensuitkyk, sy beslissings, soveel so, dat met stelligheid beweer kan word dat sy geskiedenis gans anders sou verloop het as 'n ander godsdiens aangehang is. 
Ter illustrasie kan 'n aantal van die beginsels van die Calvinisme wat sterk karaktervormende faktore is, hier genoem word en sal gesien kan word hoe hulle van die begin af rigtinggewend was in die geskiedenis van die Afrikaner.

\section{Skrifbeskouing:}

Sentraal in die Calvinisme staan natuurlik die tipies reformatoriese beginsel: sola scriptura. Alleen die Bybel. Alle godsdiens moet op die Bybel gefundeer wees. Buite die Bybel is daar geen geloofs- of ewige waarheid nie. Daarom is die Bybel die enigste bron van godsdienstige kennis en waarheid. Maar daarom ook is die Bybel die enigste norm vir alle godsdienstige lewe, sedelike lewe en gedragwyse van die gelowige mens. Dis kenbron van die waarheid maar ook handboek vir die etiek.

Hierdie basiese beginsel sou dus in die lewe van die mense aan die Kaap ook gevind word. Die Bybel het hier 'n sentrale rol in alle lewe gespeel. In die hoogste mate getrou aan hierdie reformatoriese beginsel, was dit die meesgelese boek in 'n wilde. ongetemde wêreld sonder biblioteke, universiteite of 'n pers. Elke huisgesin het hom gehad en elke dag is daaruit gelees. Van meet of aan was dit godsdienspraktyk aan die Kaap.

Dit het die vanselfsprekende gevolg gehad dat die Woord van God 'n sterk rigtinggewende en beinvloedende faktor in die wording van die nuwe volk was. Miskien was dit veral waar van die grensboere op die voorposte toe die Kolonie begin uitbrei het. Omdat ander publikasies in die wildernis nie beskikbaar was nie, was die Bybel in baie huise die enigste boek, en daarom hat dit amper 'n soort "handboek" vir die destydse Afrikaner geword en op elke lewensterrein sy gesag gehad. Afgesien van sy gebruik in die godsdiensoefening, was dit vir die nuutgebore geslagte selfs een van die weinige beskikbare middels om te leer lees en skryf en het dus 'n belangrike rol gespeel in die voorkoming van analfabetisme.

So aangewys op hierdie enigste Boek, het dit die Afrikaner se leerboek geword. Hy het oor weinig ander literatuur beskik. Sy beskouing oor natuur en natuurelemente, sy kosmologie, baie van sy politieke sieninge, sy selfbenadering, sy siening van ander volkere, sy visie op sy eie sin en betekenis in 'n nuwe, ongetemde land, het hy hieruit ontvang. Dit was beskawingsfaktor nommer een in sy lewe in die wildernis en het hom inderdaad bewaar van verwildering en opgaan in die woeste natuur met sy omringende natuurvolke. Veral die Ou Testament het hierin 'n belangrike rol gespeel, want hierdie Afrikaners het gou 'n merkwaardige parallellie tussen hulleself en die Godsvolk van 
die Ou Testament gaan sien. Hulle was soos Israel die draers van die Godsopenbaring in 'n wilde, heidense wêreld.

Uit hierdie noue verbintenis met die Bybel en met name uit die Ou Testament, het die Afrikaner ook sy visie op die gesinslewe ontvang. Die patriargale sisteem van ou Israel is netso corgeneem. Die vader is die hoof, leier en beskermheer van die gesin en staan in 'n onverbiddelike en byna absolute gesagsposisie bo sy huisgenote. Hiervoor moet hy geëer en gehoorsaam word. Dit het meegewerk tot die vorming van 'n hegte gesinsverband waarin kinders onvoorwaardelik eerbied vir die gesag van hulle ouers gehad het. Hierdie konserwatisme sou vir baie jare tipies van die Afrikanervolk wees. Die welgeordende huisgesin met sy streng dissipline en gesonde gesagsstruktuur het die basis gevorm van 'n volk wat, hoewel klein in getal, later nog 'n eervolle plek in die ry van volkere sou inneem.

\section{Godsbeskouing:}

'n Volgende kenmerk van die Calvinisme wat 'n wesenlike invloed op sy belyers uitoefen, is sy Godsbeskouing. Calvyn is altyd oorweldig deur God se majesteit, grootheid. Sy almag en Sy volslae soewereiniteit, en hierdie gevoelens het neerslag gevind in sy teologiese sisteem. Aan God is letterlik alles en almal onderworpe, gees en materie, mens en natuur en voor Hom moet almal buig. $\mathrm{Hy}$ is die vlekkeloos heilige, Gans Andere, wat tog nie in eensame en verhewe afsydigheid bly woon soos die latere Fngelse deïsme hier nie sonder gevolg sou kom leer nie, maar wat op vaderlike wyse bemoeienis met die geskapene maak. Aan Hom alleen is alle verantwoordelikheid verskuldig, deur owerheid en onderdaan.

Teenoor hierdie God staan die deur die sonde afgetakelde en gebroke mens, wegwerplik in selfs sy beste en vroomste gedaante, hulpeloos en nietig, wat slegs deur die genade van God (sola gratia) gered kan word om 'n sinvolle bestaan in die tyd en die ewigheid te voer. Daarom moet hierdie volkome afhanklike mens hom aan God en Sy wil en besluite alleen nederig onderwerp en Hom in absolute sin gehoorsaam wees. In hierdie Godsbeskouing is God Subjek en die mens objek; God besluit en die mens moet dit met dankbaarheid aanvaar. En dit op sy beurt is hierdie mens se „enigste troos in lewe en in sterwe." Want dit impliseer dat hy aan geen onpersoonlike noodlotsmag uitgelewer is nie maar aan die alwyse besluite van 'n goeie God.

'n Sodanige Godsbeskouing vorm vanselfsprekend grotendeels 'n lewens- en wêreldbeskouing. Dit kan nie sonder invloed wees nie en so was dit dan inderdaad duidelik te merk by die Calvi- 
nistiese boer aan die Kaap en hulle nageslagte. Hy was 'n Godvresende mens wat alles in en rondom sy lewe vanuit God se besluite verklaar het. Persoonlike wedervaringe, die verrigting van sy dagtaak, selfs die natuur het hy so benader. As dit droog is en sy graan vergaan, as die suidooster sy ganse oes verskroei, as plae sy ekonomiese bestaan bedreig, dan het hy daarin die hand van God gesien en altyd so, dat God hom daardeur tot verootmoediging en groter toewyding wil bring. God het 'n doel met alle rampe wat Hy oor die mens laat kom en dit was vir hom vertroostend. Die Afrikaner-Calvinis het hom altyd volkome in die hande van God toevertrou en was daarom 'n berustende soort mens, maar merkwaardig, sonder die fatalisme waartoe so 'n siening maklik aanleiding kon gee. Daar is vas geglo dat God cenvoudig vir elke mens die beste weet en die mens moet dit nie lydelik nie, maar positief aanvaar.

Dit het natuurlik daartoe meegewerk dat die Afrikaner hom altyd in sy geloof veilig gevoel het en daarom was hy basies cptimisties teenoor die lewe ingestel. Hy moes in sy geskiedenis baie krisisse in die gesig staar, in sy boerdery, in sy politiek in sy fisiesə en ekonomiese veiligheid, maar hy het kinderlik geglo: God sal hom help want Hy beskik oor alles en het met alles 'n doel. Alleen deur hierdie lewenshouding was hy daarom toegerus vir die harde, boproewende lewe in die grensdistrikte en later vir die gevare en hoë offers van die Groot Trek en die vestiging van die beskawing in die ongetemde binneland. Wie só glo, sc met 'n volkome oorgawe, kan nie juis 'n mens wees wat maklik moed verloor of in sy ideale gestuit word nie. Juis daarom het hierdie geloof so 'n bepalende rol gespeel in die verloop van die geskiedenis van die Afrikanervolk.

Die Afrikaner het in sy wordingsjare nooit 'n rasionalis geword soos sy Europese tydgenoot nie. Hy het nooit 'n Franse rewolusie geken wat die mens met sy verabsoluteerde rede bo God op die troon geplaas het nie. Hy kon nie 'n volslae materialis word nie - sy Godsbeskouing het hom daarvan weerhou. Die mens is nooit sentraal en outonoom nie - God is dit alleen. Deels vanweë hierdie Godsbeskouing en deels vanweë sy isolasie in 'n veraf land, het die groot geestesstrominge van die 18de en 19deeeue in Europa grotendeels by hom verbygegaan.

\section{Predestinasie:}

'n Derde opvallende kenmerk van die Calvinisme wat die lewensbeskouing van sy belyers help vorm, is die belangrike plek wat die predestinasieleer daarin inneem. Calvyn het die praedestinatio gemina geleer wat inhou dat God sommige mense 
tot die ewige lewe en ander tot die ewige verdoemenis voorvercrdineer het. Die mens se geloof of ongeloof is dus die gevolg van God se ewige voorbeskikking. Ook hierdie leerstuk impliseer dus dat die mens se volle lot alleen in die hande van God is. In teenstelling met wat verwag sou kon word, gee dit egter nie aanleiding tot ' $n$ gees van dooierige en selfbejammerde gelatenheid by die Calvinis nie. Want hy glo hierdie leer so, dat wie glo, wie dus gelowig kan sê dat Christus die Verlosser van die wêreld is, die is uitverkies. Hy hoef hom nooit daaroor te kwel nie. Daarom is die Calvinis wat in Christus glo inteendeel basies 'n optimistiese, hoopvolle mens. Want hy weet, wie uitverkies is, is in alle omstandighede verseker van 'n toekoms. Hy twyfel nie aan 'n sinvolle toekoms en lewensdoel nie, want dié is in Gods hand. En daarom veral is hy 'n mens met taaie volharding in moeilike en donkere omstandighede soos die Groot Trek onder andere onteenseglik bewys het. Daarom kon hy na teenspoed en vernedering telkens weer opstaan en voortgaan.

Maar verder: wie homself uitverkore weet, is ook bewus van 'n roeping wat hy in hierdie wêreld dra. Hy staan in verantwoordelikheid teenoor ander. Hy moet die lig van die verlossende Fvangelie gee aan diegene wat nog vreemd staan. Hy staan in 'n sekere voogdyskap teenoor hulle, wat juis wortel in sy kerste. ningstaak. Maar hierdie verantwoordelikheid is nie alleen 'n suiwer godsdienstige nie - die Calvinis is ook beskawingsdraer. En al sou beide hierdie opdragte problematies en soms selfs riskant wees, hy twyfel nooit, want hierdie goddelike roeping bied hom meteen ook beskerming, juis omdat dit van Gods is. Sy bewus-wees hiervan, staal hom in krisistye en bewaar hom daarvan om ooit moedeloos te word. Inderdaad was dit juis hierdie aksent van 'n Godgegewe volksroeping wat die dryfkrag was agter, en sin en betekenis gegee het aan die volgehoue stryd van die begin af om as afsonderlike entiteit voort te bestaan.

Een van die belangrikste wortels van die tradisionele rassefilosofie van die Afrikaner lê daarom diep in sy godsdiens. Heeì aan die begin van die volksplanting is geen onderskeid tussen mense bloot op grond van kleur gemaak nie. Die enigste wat wel gemaak is, was tussen heidendom en Christendom. Op bekering is 'n heiden egter onmiddellik in die Kerk opgeneem en as sodanig as gelyke behandel. So was ook die praktyk in die Ooste waar die Nederlander sy eerste kontakte met die heidendom gehad het. Aan die Kaap moes egter heel gou verandering kom. Die Europese beskouings moes vroeg hier 'n geweldige verskil in beskawingspeil byleer, iets wat in die Ooste nie die geval was nie. Hulle moes leer dat van 'n bekeerde Hottentot eenmaal nie 
maklik ' $n$ beskaafde Wes-Europiër gemaak kon word nie, trouens dit het gou, taamlik onmoontlik geblyk te wees, soos die Van Riebeecks self met die Hottentot-meidjie Eva byvoorbeeld uitgevind het. Gevolg was dat 'n nuwe rassebeskouing vorm begin aanneem het. Die lyne van verskille in die maatskaplike samestelling is deurgetrek en gekleurd het gelyk geblyk te wees aan onbeskaafd en heidens, en blank gelyk aan beskaafd en Christelik. Dit het die nuwe onderskeid geword, 'n onderskeid wat hom as't ware self aangebied het.

Maar ander elemente het mettergaan bygekom. Homself beskouende as 'n moderner openbaringsdraende „Israel”, het die Afrikanerboer wat worstel met natuur en heidendom, in die Ou Testament gelees dat Israel in sy stryd 'n uitdruklike bevel van nie-vermenging ontvang het. As Israel hom nie afsonder nie, sal hy verbaster, sal die ware geloof in gevaar kom en sal hy gestraf word. Die parallellie was vir die Afrikaner onmiddellik duidelik: hy moes nie vermeng nie en moes as blanke groep homself isoleer terwille van die geloof. En dit het sy siening en praktyk geword en daarom het hy ook nooit in die heidense massas verdwyn nie. So godsdiens het hom van verswelging deur die barbaredom gered.

Minder gelukkig in hierdie verband is 'n ou Nederlandse erfenis wat gou hier, weens omstandighede begin leef het, naamlik dat die gekleurde rasse as die vervloekte Chamskinders van die Ou Testament beskou moet word, en die feit dat veral die Hottentotte maklik gesteel en selfs gemoor het, het hierdie opvatting net versterk. 'n Gevoel van minagting teenoor die gekleurdes het by baie blankes ontstaan en hulle het hom gaan sien as iemand wat net goed is om ,houthakker en waterdraer" te wees en wat vir altyd gedoem is om net "vuilwerk" te doen. Dit het ongelukkig ender andere aanleiding gegee tot 'n arbeidsbeskouing wat SuidAfrika in later jare nog duur te staan sou kom en waarvan die wrange vrugte gepluk word. Ekonomiese - of arbeidsintegrasie is immers die grootste enkele probleem waarmee Suid-Afrika in sy rassebeleid worstel.

Maar ten spyte hiervan het die Calvinistiese Afrikaner sy roeping teenoor die heidense nasies nie vergeet nie. Hy het homself steeds gesien as voog wat hierdie nasies tot die lig van die Evangelie moes bring en hulle moes leer om 'n Christelike waardesisteem aan te hang. Maar nooit op die wyse van die filantropiese sendelinge wat in die kolonie gewerk het nie. Trouens hierdie sendelinge se optrede het by baie mense gelei tot 'n antipatie teenoor sendingwerk. Die Boer het sy kersteningswerk op sy plaas verrig, in werksure, en saans is die gekleurde 
arbeiders tot die gesin se huisgodsdiens toegelaat. En dis 'n vraag of hierdie praktyk nie veel meer vir die kerstening van die heidene gedoen het as die georganiseerde sendingpogings van die filantrope nie.

Hoofsaaklik die waardering vir en die bewaring van 'n suiwere godsdiens en nie soseer 'n politieke filosofie nie, (dit is eers veel later geformuleer) bring die Afrikaner dus tot 'n beleid van rassedifferensiasie. En dit hou hom blank en bewaar hom van verbastering.

$\mathrm{Na}$ die noordwaartse volksverhuising vind mens telkens weer hierdie beskouing wat tot uiting kom in 'n vrees vir gelykstelling. Die "tweede" Trek uit Natal is daaruit gebore. Die ewentuele inrigting van Kerk en Staat in Transvaal gee hiervan duidelik blyke. Al het dit dan byvoorbeeld 'n Kerklike isolering van die Kaap gevra, soos die Algemene Kerkvergadering van 1853 inderdaad besluit het, dan het hulle nooit gehuiwer nie. Rasseskeiding is as bestaansvoorwaarde vir 'n blanke volk en 'n suiwer godsdiens beskou.

Die apartheidsfilosofie van die Afrikaner kom dus nie van die Duiwel soos sommige beweer nie, maar kom juis uit sy godsdiens en sy Kerk.

'n Pragtige samevatting en motivering van hierdie hele gedagte word gevind in die woorde van ouderling C. J. Joubert, skriba van die Algemene Kerkvergadering van die Hervormde Kerk van 1888 - 'n tyd toe die nuwe volk al klaar sy beslag gekry het.

„Dat de grondbeginselen, „die door het volk self zijn nedergelegd en de wet van 1869 op het volgende neerkomen: Afwijzing van vreemde overheersing; en geen gelijkstelling met kleurlingen."

Die beginselen hebben onze vaderen geleid en kracht gegeven, toen zij met den bijbel in den hand, van deze woestenij een bewoonbaar oord hebben gemaakt."

\section{Verhouding Kerk en Staat.}

'n Laaste uitstaande kenmerk van die Calvinisme moet nog genoem word:

Dit is een van die weinige godsdienstige sisteme wat in sy leerstukke aandag geskenk het aan die probleem van die verhouding tussen Kerk en staat.

Calvyn het Kerk en staat geskei maar albei gesien as staande onder 'n roeping van God. Gods koningskap moet op hierdie wêreld gevestig word en die instrument daartoe is die Kerk. 
Dit beteken egter nie dat die Kerk daarom prioriteit en dus gesag bo die staat het nie. Die staat vervul in hierdie werk sy eie funksie: hy het naamlik die plig om hierdie Kerk wat hierdie funksie uitvoer, te beskerm en te bevorder. Daarvoor ontvang hy sy gesag van God. En insoverre as wat die owerheid hierdie roeping uitvoer, moet die Kerk hom respekteer en waardeer, moet die Kerk hom by die goeie orde en die gesag wat die staat ook as geroepene deur God handhaaf, neerlê. Dic Calvinisme is dus basies wetsgehoorsaam soos Rom. 13 hulle ook leer. Maar, sou 'n situasie ontstaan dat die staat hierdie roeping nie dra nie, inteendeel die Kerk verhinder om sy roeping uit te voer en daarom 'n slegte verdrukkende owerheid is, dan is die Kerk in bepaalde omstandighede verplig tot 'n ,heilige ongehoorsaamheid." Hierdie siening verteenwoordig die sterk vryheidsgedagte van die Calvinisme.

Hierdie leer het op die politieke denke van die Afrikanervolk in sy wordingsproses invloed gehad. Aan 'n simpatieke en goeie owerheid is hy basies gehoorsaam, juis omdat hy homself dan vry voel, en daarom het hy ook nooit 'n volkome wettelose mens geword nie. 'n Calvinis is nie 'n anargis nie, hoewel sy vryheidstrewe hom altyd sal laat soek na seggenskap in sy regering. Maar teen 'n onregverdige, onderdrukkende regering het hy vir homself die reg van verset en soms opstand voorbehou. Soms, veral in die grensdistrikte en in die latere republieke van Natal en Transvaal, is die vryheidsgedagte effens oordryf, maar hierdie was die basis van sy siening.

Daarom lê hier sekerlik die kiem van verset en opstande wat wel aan die Kaap plaasgevind het. Eers die Vryburgerbeweging aan die begin van die 18de eeu, dan die Patriottebeweging en die opstande in Swellendam en Graaff-Reinet aan die einde van die $18 \mathrm{de}$ eeu teen die Kompanjiesregering, en later die Slagtersnekrebellie en selfs die Groot Trek tydens die Britse bewind. Die Trek was immers niks anders as 'n daad van opstand teen ' $n$ slegte owerheid nie! Hierdie gebeurtenisse was nie gewone wetteloosheid en anargie nie, maar die Boere het eenvoudig geglo dat hulle in hierdie situasies die reg van opstand het. Die Calvinis is basies 'n demokraat en sal nooit outokrasie of politieke absolutisme sonder verset aanvaar nie en baie beslis ook nie vreemde oorheersing nie. Piet Retief se bekende manifes is ' $n$ pragtig formulering van hierdie vryheidsbeskouing:

"Ons is vasbeslote om, waar ons ookal mag gaan, die die regverdige beginsels van vryheid hoog te hou . - Ons verlaat die Kolonie onder die volledige versekering dat die Engelse regering niks meer van ons te vorder het nie en ons 
sonder verdere bemoeiing sal toelaat om ons in die toekoms self te bestuur."

En hierdie vryheidsideaal was nie 'n strewe na bandeloosheid en wetteloosheid soos veelal beweer is nie. Artikel 7 van die manifes stel duidelik dat die Trekkers beplan om vir hulleself „behoorlike wette" neer te lê en dit daarna na die Kolonie sal stuur sodat almal daarvan kon kennis neem. Die absolute outokrasie van die Engelse regering het net teen hulle gemoed en npvattings ingedruis, en dit was niks anders as hulle godsdiens wat hulle sulke sterk demokrate gemaak het nie.

Die vervolg van die geskiedenis bewys dit verder: Die reaksie op die enneksasie van Natal in 1842, van die Oranjej-Vrystaat in 1848, die jarelange onafhanklikheidsstryd van die Transvalers vanaf 1877 tot met die vernietiging van albei Boererepublieke in 1902, vind ook sy wortels hier. En wat anders het die heropbou van die Afrikanervolk vanaf 1902 tot in 1961 meegebring? Politieke oorheersing en outokrasie is vir so 'n gees eenmaal ondenkbaar en onaanvaarbaar.

Dié vryheidsstrewe van die Afrikaner wat later onder andere rorm aangeneem het in 'n Christelike nasionalisme en 'n republikanisme, was dus in sy oorsprong nie 'n humanistiese strewe soos byvoorbeeld in Europa van daardie tyd nie, maar 'n religieuse.

Daarom was dit eintlik vanselfsprekend dat die Transvaalse Kerk byvoorbeeld ook later die standpunt van geen inlywing onder die Kaapse sinode ingeneem het. Uit die notule van die eerste Algemene Kerkvergadering van 1853 kom reeds die volgende voor na aanleiding van 'n pleidooi van ds. Van der Hoff ten gunste van inlywing:

„Het punt der inlijving onzer gemeenten onder de Kaapsche Synode ter tafel komende, vraagt de leeraar het woord. Zijn Eerw. geeft den mensch te kenne dat de gemeenten alhier onder de K. Synode mogten ingelyfd worden ... De geheele vergadering is echter van een geheel ander gevoelen. Haar hoofdleus is: burgerlijk vrij en onafhankelijk, Wenschen wij dit ook in het kerkelijke. Wy wenschen onze eigene kerkelijke zaken zelf te besturen, en in deze niet ondergeschikt te zijn aan de Kaapsche Synode."

Hulle het geweet dat die Kaapse Sinode onderhorig was aan die Engelse regering.

Hierdie selfde gees het voortgeleef in die gees van die Hervormers wat in 1888 die Algemene Kerkvergadering bygewoon het en by monde van die skriba verklaar het dat hulle 
nooit met die Ned. Gereformeerde Kerk kan verenig nie omdat dié Kerk verbond was aan die Kaapse Sinode wat op sy beurt weer onder die Engelse regering gestaan het.

„Wij hebben onze geestelijke vrijheid zoo goed lief als onze staatkundige, en iedere overheersing is voor ons een onoverkomelijke hinderpaal."

Hierdie siening verklaar in ieder geval baie in die geskiedenis van die Afrikanervalk, en hieruit kan duidelik gesien word hoe die Calvinistiese Christendom die volksgees beinvloed het, 'n Latere lied uit die volksmond stel dit raak en kort:

„Ons kan geen slawe wees"!

Die Afrikaner is 'n groot liefhebber van vryheid.

\section{D. 'n Beoordeling:}

Op 'n stadium in die 18de eeu was daar van owerheidsweë 'n diepe bekommernis oor die maatskaplike en godsdienstige toestande onder die Afrikaners in die grensdistrikte. Duistere voorspellings is oor die toekoms van hierdie wordende volk gemaak.

In 1743 het kommissaris-generaal Van Imhoff 'n reis deur die binneland gemaak en ' $n$ baie ontmoedigende rapport aan die Politieke Raad voorgelê. Hy het gewag gemaak van, soos hy dit gesien het, sorgeloosheid en luiheid onder die grensboere en van 'n verwaarlosing van die godsdiens. Hulle het in die geheel 'n heidense indruk op hom gemaak en hy was diep bekommerd oor die toekoms van die mense. Hy het dan ook sekere voorstelle gedoen om die totale verval wat hy voorsien het, te verhelp.

'n Min of meer gelykluidende rapport is in 1768 deur die sekunde J. W. Cloppenburg ingedien. Hy was ook ontsteld oor die "verwildering van godsdiens" en die ongedissiplineerdheid van die Afrikanerboere. Hy het selfs 'n verval tot die barbaredom gevrees en het netsoos Van Imhoff 'n aantal voorstelle gedoen om hierdie ramp wat hy verwag het, te voorkom.

Hierdie twee here, hoe goed hulle bedoelings ookal was en hoe verdienstelik somige van hulle voorstelle ookal was, beide verkeerd waargeneem en beoordeel. Die geskiedenis van die Afrikanervolk het hulle verkeerd bewys.

Hulle was beslis nie in staat om die diepe godsdienssin van hierdie mense te peil nie. Hulle kon nie in die binnekamer sien nie; hulle was seker nie teenwoordig in die aand rondom die familietafels en vroeg in die môre wanneer huisgodsdiens gehou is nie. Feit is: al was dit gebrekkig, die godsdiens is onderhou, die beginsels van die Christendom is streng gehandhaaf en die kinders daarin opgevoed. Georganiseerde godsdiensbeoefening 
was daar nie, uiterlike seremonie om daaraan gestalte te gee, was daar nie, maar in die harte het dit geleef as 'n allesoorheersende rigtinggewende beginsel. Soos oral was die godsdiens ook hier dié kultuurbewarende en kultuurvormende faktor.

Die Afrikanervolk het nooit verval soos wat Van Imhoff en Cloppenburg gevrees het nie, trouens die fondamente van 'n eie, nuwe kultuur is hier vas en stewig gelê. Die latere geskiedenis het dit bewys toe hierdie mense na die Groot Trek hulle eie state in die binneland gestig het en al hierdie tipiese kenmerke van die Calvinisme in alles duidelik kenbaar was. Die organisasie van Kerk en godsdiens het saam met bestuursreëlings prioriteit geniet en is deurspek van 'n opregte Godsgeloof, 'n sterk vryheidsideaal en demokrasie, 'n ordelikheid en 'n deeglike roepingsbewustheid.

Al verklaring wat daarvoor gegee kan word, is die godsdiens. Dit was die fondament van hul huis, die anker om aan vas te hou, cie sleutel tot 'n nuwe toekoms. Dit het hulle daar in die vroeë begin bewaar van verwildering en opgaan in die omringende heidendom, en is daarom een van die groot redes waarom daar vandag nog 'n Afrikanervolk bestaan. Die godsdiens het die volk gemaak. En sonder die sterk vryheidsgedagte van die Calvinisme sou Suid-Afrika vandag seker veel anders daar uitgesien het.

Die godsdiens in die huis het die krisistye oorbrug. en dat dit weldeeglik daar was, kan bewys word uit vroeë verslae van kommissaris Nolthenius in 1744 en Goewerneur van Plettenberg in 1778 wat albei melding maak van 'n ernstige godsdiensbeoefening deur die grensboere. Alle uiterlike faktore was teen hulle en hulle moes eintlik verval, maar die godsdiens was die stukrag van hulle bestaan en die behoud van die beskawing.

Natuurlik het met die verloop van tyd ander invloede bygekom wat in baie opsigte die historiese karaktereie van die Afrikanervolk verander het. Die koms van die Engelse in 1806 was byvoorbeeld beslis nie 'n onvermengde seën nie. Dis werklik bemerkingswaardig hoe "Engels" die Afrikaner intussen geword het. Maar feit is: wat daar nog is van 'n tipiese Afrikaner volksaard, het hy gewis as erfenis van sy reformatoriese godsdiens. 